\title{
Playbuilding and Social Change
}

Joe Norris

\begin{abstract}
In this interview, Joe Norris reflects on his early experiences with performance and how he became involved with collective creations and playbuilding. His work has led him to develop and implement qualitative research methods using playbuilding. In his role as artistic director of Mirror Theatre, he has been the driving force behind numerous plays that inspire social change. He shares candid observations about the challenges of doing performative work and gives advice for educators wishing to pursue this kind of work.
\end{abstract}

How did you first get interested in performance and how has your career evolved since then?

In the summer after grade 4, the City of Halifax's recreation department had each playground put on a little scene from a larger play and I played the eldest son in Puss ' $n$ Boots. What is remarkable is that this year, I hired a grad student to scan many of my old documents and we found the actual program from that event.

I find that acting helps me play other sides of myself that I don't normally play. I don't completely agree with the expression, "You walk in another person's shoes." I don't think you ever can because you don't have the same history. But what acting enables me to do is play different sides of myself.

My first experiences of acting were through the summers of grade 4 to 9 . I played eldest son, Captain Hook, Chief Dogcatcher. I enjoyed that but when I went to high school, I was just overwhelmed with the experience. However, in grades 11 and 12 I was in Bye Bye Birdie and Brigadoon. I just saw Brigadoon again at the Shaw Festival and it was interesting how they changed the lines to make it politically correct these days. Again, I enjoyed the experience of playing different sides of myself. In university I did very little performing, but when I went to teach in a high school, I started to direct the high school students. And for a while working with scripted plays and amateur theatres fulfilled what I wanted.

Then I began to move into what was then called, in the early 80s, "collective creation," where actors went and researched things in communities and from that they wrote plays. I began to explore that genre, and my interest always was never to profess as much as to draw out, the one meaning of educare, to draw out for my students their personal meanings, but also to bring out a critical edge to everything we think. We began to create collective creations and when I started my doctorate with Sister Theresa Craig at the University of Alberta, my first doctoral class, I began to like the theory of voice and empowerment, but I asked, "Where are the examples in the curriculum?" Then I went back to collective creation and my whole doctoral research was observing a grade 11 drama teacher teach a collective creation course. 
Again, my concern was where are examples of student voice? When I entered the university, I found that I began to use collective creation, but it wasn't legitimate at that time as a research methodology. After about five years when I had an opportunity with Left Coast Press to write a book, I debated whether I should go with them or with a theatre publisher. I went with Left Coast Press because I really felt it would be a good advocacy platform for others as well as to legitimize what we were doing as a research methodology.

As an arts-based researcher, you've developed the genres of playbuilding and duoethnography. Can you talk a little about these?

I distinguish playbuilding from ethnodrama. Both are legitimate, both have value and I'm not negatingI'm just highlighting differences. The playbuilding is more dialogic in two ways. It's a group of A/R/Torsactors/researcher teachers - term used with permission granted from Rita Irwin et al. to adapt their version of $\mathrm{a} / \mathrm{r} / \mathrm{tography}$, but with the $\mathrm{A} / \mathrm{R} / \mathrm{Tors}$ we are continually interplaying with one another. We recognize there are multiple perspectives. I think there is a high degree of humility in that type of process as you listen to someone who disagrees with you and find that both points have legitimation. So, it was dialogic in the way we analyzed, or I would say "mediated," and that's a term I've gone to now-similar to Gadamer's concept of translation-what we do is we mediate our research. We turn it into our own thoughts, we can use art, visual, sound, music, dance, theatre, all of those, to translate. I liked that playbuilding was dialogic. I think better in a room full of people than I do alone, so part of it is my own personal style. With ethnodrama, often what happens is it's a data collected in one style, a qualitative style, and then a playwright writes a play about that data. It's a very different approach. I would say based upon different degrees of participation, it is not as dialogic. With duoethnography, it is the same.

Many years ago, Rick Sawyer and I wrote a paper about sexual orientation and presented it a couple of times, one at Provoking Curriculum, and eventually someone said, "Well, what's your methodology?" I thought to myself: I think we're inventing one. The next few years we began not only to talk about this topic, but other topics and began to create a methodology and invited other scholars to join us. I just got an email yesterday from another publisher saying, "There's another book coming out on duoethnography, will you review it prior to our acceptance?"

Growing up, we were told never to use the word "I." It was always the distancing. And I always found that strange in my own particular preference and so it's exciting that we've changed from "I" to "We," and again recognizing that different people have different life histories. We have similarities and we have differences-how can we learn from one another? Just to bring a little bit of Lévinas' concept is that we would never really understand ourselves if we were the only entity in the universe. We need the Other to help us understand ourselves.

Can you describe a couple of your most successful experiences in performance?

I'm scared to death of performance. I have stage fright. I find in the last 20 years my work is more director than performer and then "joker." I really enjoyed the improvisation because that's the second aspect I wanted to mention if I could re-circle it just a little bit. The second part of the dialogic form is that we 
give live performances to the audiences using Boal's concept of "forum theatre." We enter into dialogue with the audiences as well and we rewrite scenes and we create new scenes based on them. Most of my work has been director and, in Boal's term, joker. I find it very difficult—I know some professional actors do it, they can direct and act in a motion picture-I can't do that. I can't keep that split focus. But I would say my most successful, most moving, I would go back to Brigadoon. I walked out on stage and before they saw my plaid pants, they laughed seeing me poking through the door and obviously there was something about what I established with them that already brought an affinity. Then later on I said something like, "This Highland voodoo town makes no more sense to you than it does to me." Hearing the silence of about 1100 people was a magic moment, that I was able to bring people along with that particular story. I would say not necessarily successful as much as meaningful and impactful on me.

The other ones were actually probably post-performance: When a young woman in grade 8 in a town south of Edmonton came up to me afterwards and said, "Thank you. I thought it was going to be one of those plays that preached at us not to do drugs." She said something like, "Thank you for trusting us to be able to think through the situations on our own." One of the executives of the Students Against Drunk Driving in another southern Alberta town, came up to me after the performance and said, "Yeah you're right, it's not about preaching to them and telling them what to do, it's about helping them to think through the situations on their own." For me the performance was the post-performance reward that there were members of the audience, these were all volunteered, who really appreciated the dialogic style.

What challenges do performance educators confront in their work?

Number one, ego. I look at it in me as the chair of a department, but I find it in some of the work that I do, and I find it in myself. The way I say it is similar to when I talk about duoethnography and autoethnography and it's a semi-adaptation of Antoinette Oberg and others, is the way I phrase it: If you cast yourself as a hero or a victim, very quickly the audience is going to tire. That's where the ego rests. Yes, we are victims; yes, we are heroes, but I think that's the way we tend to our story; but I say let's cast ourselves as Frodo on a quest and let the audience determine where you are. Then that begins to remove the ego and helps you become a questioner, as someone who is lost. I think all good researchers need to be lost in the 'quest'ion and that's where the power of the (re)search is, in the struggle to find - not the answer-but the next new steppingstone or placeholder. So that's one.

Second, the challenges of working with stakeholders with a different pedagogical intent. I worked with an organization a number of years ago that were almost about to cancel a contract with us because they wanted us to do more of a presentation on "don't do drugs." They were really questioning our style until an intermediary came in and said, "No, trust Joe. We've seen his work and we know what happens." They were never convinced until they saw our first live performance with an audience. And again, there is a pedagogical difference between telling people what to do, and asking people, like problem-based learning, "What are various ways you can address this issue?" One of the things that I find is the challenge of, I think many of us would still agree, is that we're immersed in an outcomes-based curriculum that prescribe the answers. Therefore, the hidden curriculum of that is that, "experts know the answers; your job is to listen." When we work with certain groups who aren't that familiar with our work, that's what 
begins to happen. There's that challenge of trying to turn it into a format that meets the needs of the stakeholders but has a pedagogical integrity to it. So that is a challenge.

The third one-and challenges are not necessarily bad things-is whenever you enter into a dialogue with an audience, immediately after your performance, is to be prepared for a roller-coaster ride as they begin to give their ideas. I would say the personal challenge is how to both affirm and question simultaneously. If all we do is self-reaffirmation, there's no learning that takes place, no (re)search.

It's more of, "Yeah, tell your story in a trusting place, but let's also critique it." Working with people who are not familiar with the form, that can be quite daunting, and, at the same time, very successful over the years. That's a challenge that I love and I embrace, but it's exhausting work.

You are the artistic director of Mirror Theatre. Can you tell us about this work?

It's very dear to my heart. Over the years I've probably worked with close to 600 different cast members as we interrogated a wide range of social issues, and played them into performances. Our theatre started very pragmatically. We were asked to be a keynote speaker at WestCAST (Western Canadian Association For Student Teaching) and they wanted to pay us and of course they wanted to give me the money. If they gave me the money, I would have to pay income tax on it just to pay for our lodging. So, we formed a not-for-profit organization. Most of the board members are student board members and, again, throughout the process they are learning aspects of governance from being a board member. And the board members make the decisions. The projects are brought to the board, debated and approved, sometimes with questions, and that's good, and then we move forward. Mirror Theatre has been an organization for and with students.

I've been the hub throughout the years, but the hub can't work without the spokes and the rim, and the rim can't work without the hub. I do recognize my sense of artistic and pedagogical impetus in the projects, but, at the same time, I do recognize that my research would be nonexistent without this large number of committed people. Even during this COVID-19 pandemic, at their request, we're still meeting every Wednesday night. We're meeting tonight online. We're going try our first online playbuilding project on the concept of time.

What's gratifying is that there's a number of people who enjoy the process and many of them over the years have said, "I feel like it's family" every Wednesday night or Tuesday night, or whatever night. We look forward to meeting with one another and I would say it's not self-indulgent. Yes, it is; no, it isn't. We get great pleasure from meeting with one another, but at the same time we enter a level of significance in our conversations.

Finally, what words of advice do you have for educators wishing to pursue performance?

I had an article come out years ago with one of the arts journals online (International Journal of Education \& the Arts) and it talks about the use of the Great Wheel. And I use that based upon some writings from Paula Underwood. It's a way one can use the Great Wheel in various ways to help one understand themselves in the world. How I changed it was I put the four positions as: pedagogy, public, politics, and 
poetics. While I would say there's more, these are four key ones that I found in all arts-based research. Sometimes the form is forced over the product. And sometimes the product is critiqued because of its roughness, but it's so effective pedagogically and polish would interfere with that pedagogy. This chapter was a response to being at conferences where a number of people were questioning the work—not just my work-but others' works in relation to how poetic it wasn't. I think there's many perspectives on that, so I think part of it is to recognize one's intent and does it meet that intent and the feedback you get from others that you were successful in that intent. Doing performative research and performative work I would say requires looking through multiple lenses. That keeps the work relevant and appropriate. I found from time to time we live in fear of what the critic may say-and we play for the critic, and I think that's a danger. Let the work speak for itself and find the integrity between the form and the content that plays and then let it be.

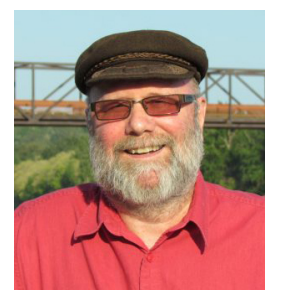

Joe Norris believes that play is a natural way of learning and that knowledge is co-constructed in the presence of Others. These underpin both his teaching and research practices. His book, Playbuilding as Qualitative Research: A Participatory Arts-based Approach, which received the 2012 Outstanding Book Award from the Qualitative Research SIG of the American Educational Research Association, describes his pioneering efforts with multiple casts of Mirror Theatre in Alberta. A second edition with Routledge Press will update with projects from Ontario casts. Examples of this work can be found at www.joenorrisplaybuilding.ca. Along with Rick Sawyer, he has developed a dialogic form of narrative research. They have coedited a special issue of the International Review of Qualitative Research and have copublished four books on the methodology with Understanding Qualitative Research: Duoethnography receiving the 2015 Significant Contribution to Educational Measurement and Research Methodology Award from the American Educational Research Association's Division D. 
28 | LEARNing Landscapes | Spring 2020, Vol. 13 